\title{
An Examination of Stock Market Anomalies: A Study in the Context of Make in India Movement
}

\author{
Vandana Khanna ${ }^{1}$ \\ ${ }^{\text {I}}$ (Associate Professor, Department of Management Studies, MMU, Sadopur-Ambala, India) \\ 1(vandanakhanna19@gmail.com)
}

\begin{abstract}
The existence of calendar anomalies is the violation of Efficient Market Hypothesis (EMH). Stock Market anomalies are the patterns that do seem to lead to abnormal returns more often than not, and since some of these patterns are based on information which is publicly visible, market anomalies present a challenge to the semi-strong form of the EMH, indicating that fundamental analysis does have some value for the individual investor. The existence and predictability of stock market anomalies has been a subject of different studies which detects empirical evidences of abnormal yield distribution. The predictable seasonal returns behavior may lead to profitable trading strategies and in turn abnormal returns. The Day-of-the-Week Effect is the most common tested anomaly in India and abroad. In the current research paper, the main focus is to examine the impact of Make in India Movement on stock market anomalies with reference to BSE Sensex. The closing prices for Sensex have been taken for the purpose of analysis. However, the investor must keep in mind that these anomalies can persist or disappear in a certain course of time.
\end{abstract}

Keywords: abnornmal returns, disappear, efficient market hypothesis, existence, predictability.

\section{INTRODUCTION}

In financial economics, the efficient-market hypothesis (EMH) states that asset prices fully reflect all available information. The EMH was developed by Professor Eugene Fama who stated that stocks always trade at their fair value. This in turn, leaves no chance for investors to either buy the undervalued securities or sell the overpriced securities. Therefore, it becomes difficult for some stocks to perform well because of expert stock selection wisdom and market timing selection. Consequently, the gain in the stock returns might be the matter of chance sometimes. The EMH states various forms of market efficiency which in turn depicts that how rapidly and correctly the stock market responses to the new available information. The new information is easily available in the market in different means through company disclosures, political announcements, company's economic reports and public surveys. Generally, as per EMH, security prices reflect all the available information prevailing in the stock market. Therefore, it becomes difficult for the investors to make any excess returns out of that information.

On the contrary, stock market sometimes documents the presence of the excess returns. These patterns are known as Calendar Anomalies. The documentation of anomalies in finance literature violates the weak form of market efficiency because equity prices are no longer follow random trend and can be predicted based on past behaviour. This in turn, facilitates market participants to prepare the trading strategies which could help them to earn abnormal returns on the basis of past performance of the stock market. Day-of-the-Week anomaly states that investors may devise a trading strategy of selling securities on Fridays and buying on Mondays in order to make excess profits. Considering economic issues, Prime Minister Mr. Narendra Modi launched 'Make in India' movement on 25th September, 2014 to invite large business houses from around the world to invest and manufacture in India. It is expected that it will result in efficient utilization in a maximum extent of Indian natural resources, labour, money, technological and machinery across the country will be possible. Consequently, this step, will create big opportunities for the new generation, produce products and services of good quality. As a result, it will help to transform India as a self relient country.

The scope of the current study is restricted to study the day-of- the week effect and weekend effect in stock returns of BSE Sensex in India in the period since when Make In India movement started in India i.e. 25th September, 2014 upto December 31, 2015. 
EMH assumes that at any given time, security prices fully reflect all available information which implies that the excess price and trading returns are not possible on any other trading day of the week (11). But the pioneering work done by a number of researchers has proved the existence of different trading returns on different trading days of the week known as Day-of-the-Week effect. Table 1 provides an overview of a number of studies representing the research work undertaken by different researchers in India and abroad. This section summarises the main conclusions drawn by them in the investigation of the Day-of-the-Week effect in stock markets, fixed income securities markets, option markets and futures market.

\section{REVIEW OF LITERATURE}

It is evident from Table 1 that a huge literature is available on Day-of-the-Week effect in developed and developing economies. The various empirical studies are supporting the refutation of EMH and different trading days of the week are documenting different trading returns. The main results presented by the financial literature investigating the Day-of-the-Week effect indicate that different trading returns on different trading days are observed not only in domestic and International stock markets, but also in bond, option and commodities markets.

Table 1 shows that negative Tuesday returns are provided in Indian and international markets (1, 2, 7, $15,23,25,30,32)$. The studies provide the evidence that negative Tuesday effect is mainly caused by the stocks with the lowest turnover ratio and the higher trading returns on Friday and Saturday (15) are observed in nonJanuary months most of the times (21). The most common explanation that has been provided for negative Tuesday's returns are that the bad news of the week-end affecting the US market can have negative influence over some other markets globally. The impact of that negative information is depicted on next day i.e. Tuesday as the market is lagged by one day (25).

Further, the correlation of Monday and Tuesday trading returns with other trading days of the week has been found (9). The reason of correlation between these two trading days might be the availability of fresh information at the start of the week which makes the trading system dynamic one relative to the rest of the week. Empirical evidences are available to support the positive Wednesday effect which is documented $(10,16,30)$

TABLE I. Empirical Evidence on Day-Of-The-Week Effect

\begin{tabular}{|c|c|c|c|c|}
\hline $\begin{array}{l}\text { Sr. } \\
\text { no. }\end{array}$ & Author & Data & Period of study & Findings \\
\hline 1. & $\begin{array}{ll}\text { Loughani } & \text { and } \\
\text { Chappel (2001) } & \end{array}$ & KSE (Kuwait) & 1993-1997 & $\begin{array}{l}\text { Trading returns are highest on the first trading } \\
\text { day of the trading week. }\end{array}$ \\
\hline 2. & $\begin{array}{l}\text { Bayar and Kan } \\
(2002)\end{array}$ & $\begin{array}{l}\text { Stock indices of Australia, Austria, } \\
\text { Belgium, Canada, Denmark, Finland, } \\
\text { France, Germany, Hong-Kong, Italy, } \\
\text { Japan, The Netherlands, New Zealand, } \\
\text { Norway, Spain, Sweden, Switzerland, UK } \\
\text { and USA. }\end{array}$ & 1993-1998 & $\begin{array}{l}\text { Volatility is lowest towards the end of the week } \\
\text { in local currency returns and on Tuesday in } \\
\text { terms of dollar returns. }\end{array}$ \\
\hline 3. & Hellstrom (2002) & 207 stocks (Sweden) & $1987-1996$ & $\begin{array}{l}\text { (+ve) Tuesday and (-ve) Friday effect is } \\
\text { confirmed. }\end{array}$ \\
\hline 4. & $\begin{array}{l}\text { Bhattacharya et al. } \\
(2003)\end{array}$ & BSE 100 Index & $1991-2000$ & (+ve) Fri. return and (+ve) Thus. return. \\
\hline 5. & $\begin{array}{l}\text { Kiymaz and } \\
\text { Berument (2003) }\end{array}$ & $\begin{array}{l}\text { 1. TSE-Composite (Canada) } \\
\text { 2. DAX (Germany) } \\
\text { 3. Nikkei-225 (Japan) } \\
\text { 4. FT-100 (UK) } \\
\text { 5. NYSE-Composite (NYSE) }\end{array}$ & $1988-2002$ & $\begin{array}{l}\text { High volatility is accompanied with low trading } \\
\text { volume. }\end{array}$ \\
\hline 6. & Kaur (2004) & $\begin{array}{l}\text { 1. BSE Sensex } \\
\text { 2. S \& P CNX Nifty } \\
\text { 3. S \& P } 500 \text { (US) } \\
\text { 4. NASDAQ (US) }\end{array}$ & $1993-2003$ & (+ve) Wed. returns. \\
\hline 7. & $\begin{array}{l}\text { Lian and Chen } \\
(2004)\end{array}$ & $\begin{array}{l}\text { 1.Kaula Lumpur Stock exchange } \\
\text { Composite Index (Malaysia) } \\
\text { 2.Singapore Stock Exchange (Singapore) } \\
\text { 3.Jakarta Composite Index (Indonesia) }\end{array}$ & $1992-2002$ & $\begin{array}{l}\text { Day-of-the-Week effect exists. Different trading } \\
\text { day's returns have been found in different sub- } \\
\text { periods. }\end{array}$ \\
\hline
\end{tabular}


IOSR Journal of Business and Management (IOSR-JBM)

e-ISSN: 2278-487X, p-ISSN: 2319-7668

\begin{tabular}{|c|c|c|c|c|}
\hline & & $\begin{array}{l}\text { 4.Thailand Index (Thailand) } \\
\text { 5.Philippines } \quad \text { Composite } \quad \text { Index } \\
\text { (Philippines) }\end{array}$ & & \\
\hline 8. & $\begin{array}{l}\text { Nath and Dalvi, } \\
(2004)\end{array}$ & S\&P CNX Nifty & $1999-2003$ & $(+v e)$ Wed. return and $(+v e)$ Fri. return. \\
\hline 9. & Savva et al. (2004) & $\begin{array}{l}\text { 1. DAX-30 (Germany) } \\
\text { 2. FTSE-100 (UK) } \\
\text { 3. CAC-40 (France) } \\
\text { 4. IBEX-35 (Spain) }\end{array}$ & 1993-2005 & $\begin{array}{l}\text { Negative news have greater impact on the } \\
\text { market than the positive news. Spain, Greece, } \\
\text { Finland, Netherlands, Denmark and Norway } \\
\text { have exhibited Day-of-the-Week effect in } \\
\text { trading returns. }\end{array}$ \\
\hline 10. & $\begin{array}{l}\text { Holden and } \\
\text { Thompson (2005) }\end{array}$ & $\begin{array}{l}\text { 1. ATX (Austria) } \\
\text { 2. DAX (Germany) } \\
\text { 3. BUX (Hungary) } \\
\text { 4. WIG (Poland) } \\
\text { 5. PIX (Czech Republic) } \\
\text { 6. FTSE } 100 \text { (UK) } \\
\text { 7. FTSE } 250 \text { (UK) } \\
\text { 8. S \& P } 500 \text { Share price (US) }\end{array}$ & $\begin{array}{l}1994-2004 \\
1994-2004 \\
1994-2004 \\
1994-2004 \\
1995-2004 \\
1986-2004 \\
1986-2004 \\
1984-2005\end{array}$ & $\begin{array}{l}\text { No Day-of-the-Week effect is present in USA } \\
\text { returns and very little evidence for Monday } \\
\text { effect is found in Austria, Hungary, Germany, } \\
\text { Czech Republic and Poland. }\end{array}$ \\
\hline 11. & $\begin{array}{l}\text { Keef and Roush } \\
(2005)\end{array}$ & S \& P 500 (US) & $1930-1999$ & $\begin{array}{l}\text { Monday effect is absent in Pre-Holiday trading } \\
\text { returns in the pre 1987era. The mean trading } \\
\text { returns on the day before holiday falling on } \\
\text { Wednesday are four times larger than the typical } \\
\text { Pre-Holiday. }\end{array}$ \\
\hline 12. & $\begin{array}{l}\text { Mangala and Mittal, } \\
(2005)\end{array}$ & CNX Nifty Junior & $1997-2003$ & (+ve) Wed. return and (-ve) Fri. return. \\
\hline 13. & Peng (2005) & ASX (Australia) & $1992-03$ & Tuesday effect is present. \\
\hline 14. & Yakob et al. (2005) & $\begin{array}{l}\text { Daily closing returns of Australia, China, } \\
\text { Hong Kong, Japan, India, Indonesia, } \\
\text { Malaysia, South Korea and Taiwan. }\end{array}$ & $\begin{array}{l}\text { Jan, } 2000- \\
\text { March, } 2000 .\end{array}$ & $\begin{array}{l}\text { Day-of-the-Week effect is found in Indonesia, } \\
\text { China, Australia and Taiwan. }\end{array}$ \\
\hline 15. & $\begin{array}{l}\text { Apolinario et } \text { al. } \\
\text { (2006) }\end{array}$ & $\begin{array}{l}\text { Daily closing returns of Germany, Austria, } \\
\text { Belgium, Denmark, Spain, France, The } \\
\text { Netherlands, Italy, Portugal, The United } \\
\text { Kingdom, The Czech Republic, Sweden } \\
\text { and Switzerland. }\end{array}$ & $1997-2004$ & $\begin{array}{l}\text { Monday effect is present in French and Swedish } \\
\text { markets. Day-of-the-Week effect is present in all } \\
\text { the financial markets except Portugal and Czech } \\
\text { Republic. }\end{array}$ \\
\hline 16. & $\begin{array}{l}\text { Boynton et al. } \\
(2006)\end{array}$ & PACAP VW index (Hong-Kong) & $1975-2001$ & $\begin{array}{l}\text { Until 1990s, Tuesday has exhibits abnormal } \\
\text { losses. In } 1990 \text { s, Monday is exhibiting (-ve) } \\
\text { return and there is a decrease in volume as well. }\end{array}$ \\
\hline 17. & Davidson (2006) & S \& P 500 (US) & $1970-2005$ & $\begin{array}{l}\text { Monday has lowest trading returns and } \\
\text { Wednesday has exhibited the highest trading } \\
\text { returns. }\end{array}$ \\
\hline 18. & $\begin{array}{l}\text { Mazumdar et al. } \\
\text { (2006) }\end{array}$ & SPDRS (US) & $1996-2003$ & $\begin{array}{l}\text { Thursday effect is found and highest standard } \\
\text { deviation is found on Monday. }\end{array}$ \\
\hline 19. & $\begin{array}{l}\text { Sharma and Singh } \\
\text { (2006) }\end{array}$ & BSE Sensex (India) & $1992-2005$ & $\begin{array}{l}(-\mathrm{ve}) \text { Tues. and (+ve) Wednesday trading } \\
\text { returns. }\end{array}$ \\
\hline 20. & $\begin{array}{l}\text { Wickremasinghe } \\
\text { (2007) }\end{array}$ & $\begin{array}{l}\text { Daily and monthly share prices of } 75 \\
\text { Companies (Sri Lanka) }\end{array}$ & 1987-1999 & (-ve) Tues. and (-ve) Wed. effect has been found. \\
\hline 21. & $\begin{array}{l}\text { Kenourgios and } \\
\text { Samitas (2008) }\end{array}$ & $\begin{array}{l}\text { ASE Index } \\
\text { Three major industry Index } \\
\text { FTSE- } 20 \\
\text { FTSE- } 40\end{array}$ & $1995-2000$ & $\begin{array}{l}\text { Stock market anomaly has weakened in both } \\
\text { returns and volatility. }\end{array}$ \\
\hline 22. & $\begin{array}{l}\text { Ali and Akbar } \\
(2009)\end{array}$ & KSE 100 VW Index (Karachi) & $1991-2006$ & Thursday effect has been documented. \\
\hline 23. & Rahman (2009) & $\begin{array}{l}\text { DSI (Dhaka) } \\
\text { DGEN (Dhaka) } \\
\text { DSE } 20 \text { (Dhaka) }\end{array}$ & $2005-2008$ & (-ve) Monday and (+ve) Thursday returns. \\
\hline 24. & $\begin{array}{l}\text { Singhal and Bahure } \\
\text { (2009) }\end{array}$ & $\begin{array}{l}\text { BSE Sensex (India) } \\
\text { BSE } 200 \text { (India) } \\
\text { S \& P Nifty (India) }\end{array}$ & $2003-2008$ & (+ve) Fri. returns in all the three indices. \\
\hline
\end{tabular}


Where, AMEX EW = America Stock Exchange Equally weighted, AMEX VW = America Stock Exchange Value-weighted, ASX = Australian Index, ATX = Austrian Traded Index, BSE = Bombay Stock Exchange, BUX = Budapest Stock Exchange Index, CAC = Cotation Assiste En Continu, CNX = Crisil and National Stock Exchange Index of Fifty Stocks, DAX = Deutsche Aktien Indexe, DGEN = DSE General Index, DJIA = Dow Jones Industrial Average, DM = German Ma, DSI = Dhaka All Share Price Index, FT = Financial Times, Fri $=$ Friday, FTSE $=$ Financial Times Stock Exchange, HSI = Hang-Sang Index, IBEX = Iberia Index, ISECI = Istanbul Securities Exchange Composite Index, JCI = Jakarta Composite Index, KLSECI = Kuala Lumpur Stock exchange Composite Index, KSC = Korea South Composite, KSE = Karachi Stock Exchange, KUSE = Kuwait Stock Exchange, Mon = Monday, MSEC = Manila Stock Exchange Composite, NASDAQ EW = National Association of Security Dealers Automated Quotational Equally Weighted, NASDAQ VW = National Association of Security Dealers Automated Quotational Value Weighted, NYSE = New York Stock Exchange, PACAP VW = Pacific Basin Capital Market, PIX = Private Internet Exchange, SES = Stock Exchange of Singapore, SETI = Securities Exchange of Thailand Index, S \& P $500=$ Standard \& Poor, SPDRS = Standard and Poor's Depository Receipts, TL = Turkish Lira, TSEI = Taiwan Stock Exchange Index, TOPIX =Tokyo Stock Price Index, Tues = Tuesday, USD = US Dollar, Wed = Wednesday, WIG = Warszawski Indeks Gieldowy, (+) indicates positive and (-) indicates negative trading returns on the particular day.

Source: Compiled from Various Research Studies.

The literature has supported that the reason for positive Wednesday trading returns might be due to the optimistic attitude of the Indian investors to make their dealings on Wednesday most of the times $(2,12,27,30)$ In Indian capital market, a number of studies have documented the positive Thursday effect $(6,8,26)$.

There are some studies which are available to support the positive Friday effect $(6,25,31)$ in the Indian stock market. The cause suggested by some of the pioneer studies for this particular effect might be the uncertainty of the opening position of the stock market on Monday. Some of the Indian researchers i.e. Goswami and Anshuman 2000; Bhattacharya et al. 2003 have employed the data based on mid-1980s and mid-1990s in their studies. All these studies except $(6,8)$ have used conventional methods like serial autocorrelation tests and or fitting an Ordinary Least Square (OLS).

The foregoing review of literature will be of immense help to the academicians, market investors, practitioners, market agents and regulatory authorities to understand whether information dissemination at Week-Ends affects the trading returns on other trading days or not. In such a way, empirical findings of the study can guide the future policy framework to exploit the opportunities arising in the stock market.

\section{DATA BASE AND METHOdOLOGY}

The data constitutes a sample of 313 daily close-to-close observations for BSE-Sensex. The present study has selected the sample for the period from September 25, 2014 through December 31, 2015.

For the purpose of analysis, daily stock prices have been converted to daily returns. The present study employs the logarithmic difference for the first order as the logarithmic difference is symmetric between up and down movements and is expressed in percentage terms for ease of comparability with the idea of percentage change. If Pt be the closing level of prices on date $\mathrm{t}$ and Pt-1 be the same for the previous business day (omitting intervening weekend or stock exchange holidays), then the one day return on the market portfolio is calculated as:

$\mathrm{R}_{\mathrm{t}}=\log (\mathrm{Pt} / \mathrm{Pt}-1)$

Descriptive analysis has been used to examine Day-of-the-Week and Day-of-the-Week effect in Indian stock market.

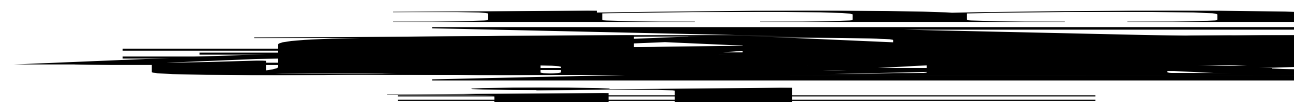

Where,

$$
\text { Di }=\left\{\begin{array}{c}
1: \text { ith day } \\
; \mathrm{i}=\text { Tues, Wed, Thurs, Fri } \\
0: \text { otherwise }
\end{array}\right.
$$

\section{ANALYSIS \& INTERPRETATIONS}

EMH assumes that the returns for all trading days of the week are equal, which implies that in the market nobody has the capacity to secure abnormal returns. The results from analysis refute the existence of EMH and provide the evidence of existence of day-of-the-week anomaly in Indian stock market. The descriptive 
statistics has been used for the analysis for the entire study period and with a view to obtain the overall assessment of Indian capital market to examine the features of the return distributions.

\begin{tabular}{|c|c|c|c|c|c|c|}
\hline \multicolumn{7}{|c|}{ TABLE II. Descriptive Statistics (Sensex) } \\
\hline Variables & $\mathbf{N}$ & Mean & Maximum & Minimum & $\begin{array}{c}\text { Standard } \\
\text { Deviation }\end{array}$ & Skewness \\
\hline Monday & 64 & 0.219 & 3.11 & -1.83 & 0.923 & 0.964 \\
\hline Tuesday & 65 & -0.029 & 2.66 & -1.57 & 0.861 & 0.593 \\
\hline Wednesday & 64 & -0.168 & 2.35 & -2.62 & 0.904 & 0.0220 \\
\hline Thursday & 59 & -0.117 & 2.20 & -2.13 & 0.953 & 0.0421 \\
\hline Friday & 59 & 0.112 & 6.11 & -1.86 & 1.199 & 2.169 \\
\hline Total & 311 & 0.004 & 6.12 & -2.62 & 0.976 & 1.010 \\
\hline
\end{tabular}

From the above Table, it has become evident that the trading returns in the period undertaken are not independent across different trading days and Indian stock market has proved inefficient, indicated the seasonal nature of Indian stock market. The trading returns are found highest on Monday, which is known as "Reversal of Monday Effect". The literature documents the presence of "Monday Effect, which states that trading returns are lowest and sometimes negative on Monday. But, the current study documents the opposite scenario of that. It clearly replicates that the Indian stock market is moving towards the efficiency.

However, trading returns are found lowest on Tuesday. Thus, a strong evidence for the presence of day of the week anomaly has been documented. Therefore, it is evident that the results from the above analysis refute the presence of EMH and help the investors by timing their strategies in advance to exploit the maximum benefit from trading activities. Summarizing the results of BSE-Sensex, there are different trading returns on different trading days in the period. The study has covered the period when the Make in India Project has been started in India. Reversal of Monday effect is found for the period.

\section{CONCLUSION}

The summary results of descriptive analysis of BSE-Sensex demonstrate that Monday is causing the highest variability in the weekly distribution of mean returns during the period. From the above discussion, it can be concluded that trading anomalies provide an opportunity to the investor with reference to the period undertaken in the context of Day-of-the-week effect help to earn maximum benefit, so that they might earn super-normal profits by keeping their investment decisions based on the purchase of securities on the day with lowest possible mean returns and sell them on a day which is providing the maximum possible average trading returns. The results clearly indicate that Indian stock market is moving towards the efficiency due to the presence of Reversal of Monday Effect. Above findings could possibly help in understanding and explaining stock market anomalies for the Indian capital markets. Hence, the need of the hour is to further look for the alternative explanations and to search for some new aspects related to the existing factors. Furthermore, the regulatory bodies, institutional investors and public figures may get a positive and creative impact on the presence and persistence of investment planning in the context of Day-of-the-Week effect.

\section{REFERENCES}

[1] S. Ali and M. Akbar, "Calendar Effects in Pakistani Stock Market", International Review of Business Research Papers, 5(1), 2009, 389-404.

[2] S. Amanulla and M. Thiripalraju, "Week End Effect: New Evidence from the Indian Stock Market", Vikalpa, 26(2), 2001, 33-50.

[3] R. Anshuman, and R. Goswami, "Day of the Week Effects on the Bombay Stock Exchange", The ICFAI Journal of Applied Finance, 6(4), 2000, 31-41.

[4] R. Apolinario, et al. "Day-of-the-Week Effect on European Stock Markets", International Research Journal of Finance and Economics, 2, 2006, 53-70.

[5] A. Bayar, and O. Kan, "Day of the Week Effects: Recent Evidence from Nineteen Stock Markets", Central Bank Review, 2, $2002,77-$ 90.

[6] K. Bhattacharya, et al. "Stability of the Day of the Week Effect in Return and in Volatility at the Indian Capital Market: A GARCH Approach with Proper Mean Specification”, Applied Financial Economics, 18(8), 2003, 553-563. 
[7] W. Boynton, et al., Japanese Day of the Week-End Return Patterns: New Results, 2006.

[8] T. Choudhry, "Day of the Week Effect in Emerging Asian Stock Markets: Evidence from the GARCH Model", Applied Financial Economics, 10, 2000, 235-242.

[9] Demirer, "An Investigation of Day-of-the-Week Effect on Stock Returns in Turkey", 2006.

[10] M. Davidson, "Stock Market Anomalies, A Literature Review and Estimation of Calendar Effects on the S\&P 500 Index", Bachelor Thesis in Economics, Jonkoping International Business School, Jonkoping University, 2006.

[11] P. Draper, and K. Paudyal, "Explaining Monday Returns, The Journal of Financial Research”, 25(4), 2002, 507-520.

[12] M. Gupta, and N. Aggarwal, "Day of the Week Effect: Empirical Evidence from Indian Stock Market, Paradigm”, 8(2), 2004, 9-13.

[13] T. Hellstrom, "Trends and Calendar Effects in Stock Returns", 2002.

[14] Holden and Thompson K. et al. (2005), "The Asian Crisis and Calendar Effects on Stock Returns in Thailand", European Journal of Operational Research, 163, 2005, 242-258.

[15] Hu, O. et al. Short Sales, Stock Liquidity and the Day of the Week Effect: The Taiwan Stock Market Evidence, (2006).

[16] H. Kaur, "Time Varying Volatility in the Indian Stock Market", Vikalpa, 29(4), 2004, 25-42.

[17] S. Keef, and M. Roush, "Day of the Week Effects in the Pre-Holiday Returns of the Standard and Poor 500 Stock Index", Applied Financial Economics, 15, 2005, 107-119.

[18] D. Kenourgios, and A. Samitas, "The Day-of-the-Week Effect Patterns on Stock Market Return and Volatility: Evidence for the Athens Stock Exchange", International Research Journal of Finance and Economics, 15(15), 2008, 78-89.

[19] H. Kiymaz, and H. Berument, "The Day of the Week Effect on Stock Market Volatility and Volume: International Evidence", Review of Financial Economics, 12(4), 2003, 463-480.

[20] K. Lian, and W. Chen, "Seasonal Anomalies of Stocks in Asean Equity Markets", Sunway College Journal, 1, 2000, 1-11.

[21] T. Lin, and L. Lim, On the Disappearance of Tuesday Effect in Australia, 2001.

[22] A. Loughani, and D. Chappel, "Modelling the Day of the Week Effect in Kuwait Stock Exchange: A Non Linear GARCH Representation", Applied Financial Economics, 11, 2001, 353-359.

[23] D. Mangala, and R. Mittal, "Efficiency of Indian Stock Market-An Evidence of Day of the Week Effect”", Gyan, 1, 2005, 3-8.

[24] M.I., Mazumder, T-H., Chu , E.M., Miller, L.J., Prather, "International day-of-the-week effects: An empirical examination of iShares", International Review of Financial Analysis, 17 (4), 2006, 699-708.

[25] G. Nath, and M Dalvi,. "Day of the Week Effect and Market Efficiency: Evidence From Indian Equity market Using High Frequency Data of NSE", The ICFAI Journal of Applied Finance, 2(2), (2004), 1-16.

[26] M. Rahman, "Stock Market Anomaly: Day of the Week Effect in Dhaka Stock Exchange", International Journal of Business and Management, 4(5), 2009, 193-206.

[27] R. Ranjan, and A. Padhye, Market Anomalies in Emerging Markets: Revisiting the Calendar Effect in Stock Prices, 2000.

[28] Savva et al. "The Day of the Week Effect in Fifteen European Stock Markets", 2006,

[29] V. Sharmaand B. Singh, "Day of the Week Effect and Indian Stock Market", Paradigm, 10(1), 2006, 31-43.

[30] A. Singhal and V. Bahure, "Week-End Effect of Stock Returns in the Indian Market", Great Lakes Herald, 3(1), 2009, $12-22$.

[31] G. Wickremasinghe "Seasonality of Emerging Stock Markets: Evidence from the Colombo Stock Exchange", The ICFAI Journal of Applied Finance, 13(6), 2007, 43-65.

[32] Yakob et al, "Seasonality in the Asia Pacific Stock Markets", Journal of Asset Management, 6(4), 2005, 298-318. 